\title{
Selected features of carbonate rocks based on the X-ray computed tomography method (CT)
}

The paper presents possibilities of X-ray computed tomography (CT) application in view of representing selected features of carbonate rocks in a CT image. 72 sections of drill cores, approx. $1 \mathrm{~m}$ long each, were selected for tomographic examinations to obtain as reliable as possible results. The selected core material represents carbonate formations of various ages (from Palaeozoic to Upper Cretaceous), originating from boreholes situated in the Carpathian Foreland area. The interpretation of tomographic examinations was connected with a detailed sedimentological analysis of selected core sections, allowing to carry out direct comparisons, which of studied features and to what extent have disclosed in the CT images, and also whether this image can supplement or make the prepared descriptions more detailed. The presented information has a qualitative nature, i.e. referring mainly to descriptive features of the analysed carbonate rocks. Because of a limited size of the paper we have focused only on a few from numerous analysed features of carbonate rocks. The method of X-ray computed tomography (CT) can be very helpful at the analysis of various carbonate rocks features, such as structural and textural features, biogenic structures, porosity, and fracturing. It should be emphasised that this is a non-invasive method, providing a possibility to reproduce the CT image in various directions, without the necessity of mechanical interference in the rock material, resulting in the core destruction. Mummified siliceous sponges were examples of biogenic structures, which were best reflected in formations, which have been subjected to processes of selective dolomitization. In such type of carbonate rocks the sponge mummies were not dolomitized, while the basic material of the background was dolomitized. A very good representation of the structure in CT images was obtained for colonial hexacorals from the Scleractinia group, because many details of their skeleton structure are noticeable. Contrary to siliceous sponges the structure of corals is preserved much worse in the case, when the studied deposits were subject to diagenetic processes (such as dissolution, recrystallisation, or dolomitization). In addition, the analysis of various bioclasts, preserved in carbonate rocks, has shown a significant role both of the original mineral component building the skeletal elements of organisms (aragonite, high-magnesium calcite, low-magnesium calcite), and of diagenetic processes history, directly affecting the condition of those components preservation. Based on the analysed materials it was found that porosity and fracturing are among best reflected features of carbonate rocks in the CT image. Open fractures, fractures filled with anhydrite and fractures filled with clay-marly material are generally well reflected in the CT image. Instead, fractures filled with calcite are variously recognisable, depending on the mineral composition of the rock background.

Key words: X-ray computed tomography, carbonate rocks, textural features, biogenic structures, porosity, fractures.

\section{Wybrane cechy skał węglanowych w odwzorowaniu rentgenowskiej tomografii komputerowej (CT)}

W artykule przedstawiono możliwości wykorzystania rentgenowskiej tomografii komputerowej (CT) pod kątem odzwierciedlenia wybranych cech skał węglanowych w obrazie CT. Do badań tomograficznych wytypowano 72 odcinki rdzeni wiertniczych o długości ok. 1 m każdy w celu uzyskania możliwie najbardziej wiarygodnych wyników. Wytypowany materiał rdzeniowy reprezentuje utwory węglanowe różnego wieku (od paleozoiku po górną kredę), pochodzące z otworów wiertniczych, zlokalizowanych na obszarze przedgórza i w podłożu Karpat. Interpretację badań tomograficznych powiązano ze szczegółową analizą sedymentologiczną wybranych odcinków rdzeni, co pozwoliło na bezpośrednie porównanie, które z badanych cech i w jakim stopniu ujawniły się w obrazie tomograficznym, a także czy obraz ten jest w stanie uzupełnić lub uszczegółowić wykonane opisy. Przedstawione informacje mają charakter jakościowy, tj. odnoszący się głównie do cech opisowych analizowanych skał węglanowych. W związku z ograniczoną objętością artykułu skoncentrowano się jedynie na kilku spośród wielu przeanalizowanych cech skał węglanowych. Metoda rentgenowskiej tomografii komputerowej (CT) może być bardzo pomocna przy analizie różnego typu ich cech, takich jak: cechy strukturalne i teksturalne, struktury biogeniczne, porowatość, szczelinowatość. Należy podkreślić, że jest to metoda nieinwazyjna, dająca możliwość odtwarzania obrazu tomograficznego w różnych kierunkach, bez konieczności mechanicznej ingerencji w materiał skalny, prowadzącej do niszczenia rdzenia. Spośród przeanalizowanych struktur biogenicznych uwagę zwrócono na zmumifikowane gąbki krzemionkowe, które w najlepszym 
stopniu odwzorowane zostały w zapisie CT w utworach, które w trakcie diagenezy poddane zostały procesom selektywnej dolomityzacji. W tego typu utworach mumie gąbek nie uległy dolomityzacji, podczas gdy masa podstawowa otaczającego osadu została zdolomityzowana. Bardzo dobre odzwierciedlenie struktury w zapisie CT uzyskano dla kolonijnych koralowców sześciopromiennych z grupy Scleractinia, gdyż w obrazie tomograficznym dostrzegalnych jest wiele detali budowy ich szkieletu. W przeciwieństwie do gąbek krzemionkowych, struktura koralowców zachowana jest znacznie gorzej w przypadku, gdy badane utwory poddane zostały w większym stopniu procesom diagenetycznym (takim jak rozpuszczanie, rekrystalizacja czy też dolomityzacja). Ponadto analiza różnego typu bioklastów, zachowanych w skałach węglanowych, wykazała istotną rolę, zarówno pierwotnego składnika mineralnego budującego elementy szkieletowe organizmów (aragonit, kalcyt wysokomagnezowy, kalcyt niskomagnezowy), jak również historii procesów diagenetycznych, mających bezpośredni wpływ na stan zachowania tych elementów. Na podstawie przeanalizowanych materiałów stwierdzono, że porowatość i szczelinowatość są jednymi z najlepiej odwzorowanych w zapisie tomograficznym cech skał węglanowych. W obrazie CT na ogół w bardzo dobrym stopniu czytelne są szczeliny otwarte, szczeliny wypełnione anhydrytem oraz szczeliny wypełnione materiałem ilasto-marglistym. Natomiast szczeliny zabliźnione kalcytem rozpoznawalne są w różnym stopniu, w zależności od składu mineralnego tła skalnego.

Słowa kluczowe: rentgenowska tomografia komputerowa, skały węglanowe, cechy teksturalne, struktury biogeniczne, porowatość, szczeliny.

\section{Introduction}

The X-ray computed tomography (CT), being the basic research method used within this study, is an efficient tool to analyse drill cores, ensuring a non-destructive testing of rocks and illustrating their internal structure, with particular emphasis on sedimentation structures as well as on their pore structure nature. Other applications of X-ray computed tomography method, which can be quoted based on the literature, include selecting sampling places on non-cut cores, assessment of drilling fluid invasiveness in drill cores [4], assessment of rocks structure anisotropy [45], analysis and spatial imaging of rock environment pore structure [5], observation of rock structure change during mechanical testing [42], and extrusion of brine by $\mathrm{CO}_{2}$ injection [27].

Carbonate rocks are a group of rocks very difficult to interpret due to a high variability of a number of parameters, such as lithology, mineral composition, biogenic structures content, texture, porosity, permeability, and others. The studies on clastic and evaporate rocks by means of X-ray computed tomography carried out under previous projects provided very good results, allowing a moderately detailed description of many diverse rock features $[3,47]$. The computed tomography methodology, because of its specific nature of density diversifi- cation determination for a rock medium, has a high potential to obtain better resolution with respect to certain features, directly invisible in the core (e.g. due to a homogeneous colour of the deposits). This method allowed also to make the interpretation results of micro imager XRMITM more detailed, providing a possibility to interpolate individual features onto non-cored sections of the profile [47].

On the basis of obtained results of computed tomography application it is possible to state that this method can be very helpful when analysing various features of carbonate rocks (such as biogenic and sedimentation structures, studies on the spatial system of fractures network), in particular in the case, when only the archive part of core is available. Because this is a non-invasive method, providing a possibility to reproduce the CT image in various directions, without the necessity of mechanical interference in the rock material, resulting in the core destruction.

The realization of the X-ray computed tomography before halving the core can be very useful for the core documentation and archiving. The tomographic examination allows to preserve a complete image of the core, which later on can be used for various analyses and interpretations.

\section{Methodology}

Methodology details of drill cores examination by means of X-ray computed tomography (CT) were presented in the paper by Wolański et al. [47]. The measurements result directly in obtaining three dimentional image of the core in the greyscale. Light colours of the image correspond to core fragments with a high X-ray absorption (density), and the dark colours of the image correspond to areas of low absorption (density).
The core material, studied by the authors of this paper, featured a very high diversity in lithofacial terms. The results of studies are presented mostly on unified patterns, containing a photography of the analysed core section, CT reconstruction using the greyscale and colour scales (selected from the following colour scales of the ImageJ application: blue orange icb, ICA, Red Hot, and HiLo), so as to represent as good as possible individual described features of the examined rocks. 


\section{Analysis of reconstruction possibilities for selected carbonate rock features based on the tomographic scan}

\section{Stylolites}

Stylolites are textural elements in the form of uneven surfaces which observed in a vertical cross-section have a shape of a serrated, prismatic or wavy seam, thickened with an clay coat or interlayer [37]. They originate as a result of selective dissolution of carbonates under the increasing overburden pressure (chemical compaction). The amplitude of stylolitic seams can vary, from a few millimetres to $5 \div 6 \mathrm{~cm}[18]$.

In the studied examples the stylolitic seams were recorded generally quite well in the CT image and were easily identifiable, mainly due to the concentration of clay minerals on their surface. An example of a typical image for stylolites is presented in Figure 1. Figure 2 presents a stylolite image in a cross-section.

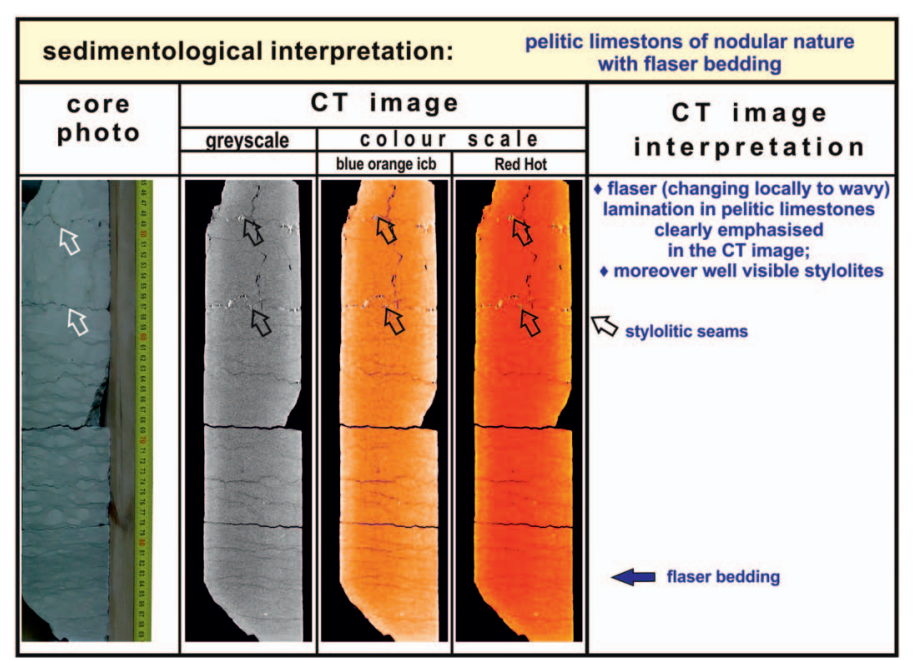

Fig. 1. CT image interpretation for a series of pelitic limestones with stylolites
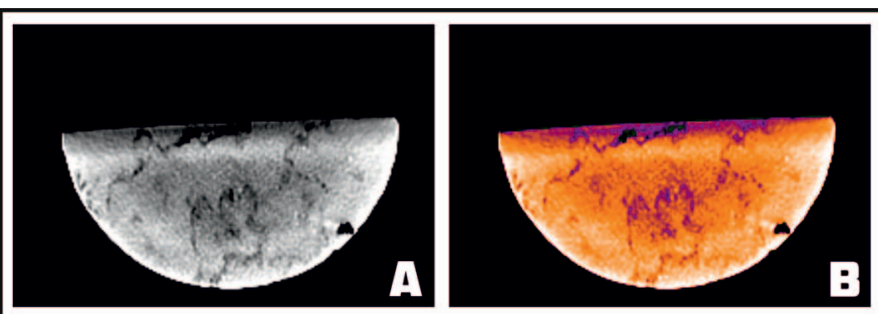

Fig. 2. An example of stylolitic seams in the CT image (cross-section); A - using the greyscale, B - using the blue orange icb colour scale

\section{Dolomitization}

Dolomitization is a process of partial or total calcium carbonate (calcite) transformation into calcium and magnesium carbonate (dolomite), proceeding most often as a result of the action of solutions enriched with magnesium ions. Dolomitization effects were among the most frequent diagenetic pro- cesses, which were diagnosed in studied formations, and their intensity was highly diversified. Such processes have frequently a selective nature, consisting in dolomitization of only certain parts (of various ranges) of the profile. The Upper Jurassic rocks presented in Figure 3 are an example of such selective dolomitization. The X-ray computed tomography images analysis can help in the assessment of dolomitization degree, because it allows to distinguish the parts of profile characterized by smaller and higher dolomitization intensity (Figure 3). However, more intense dolomitization results usually in erasing the original structural features of a carbonate rock, which become almost illegible in the $\mathrm{CT}$ image.

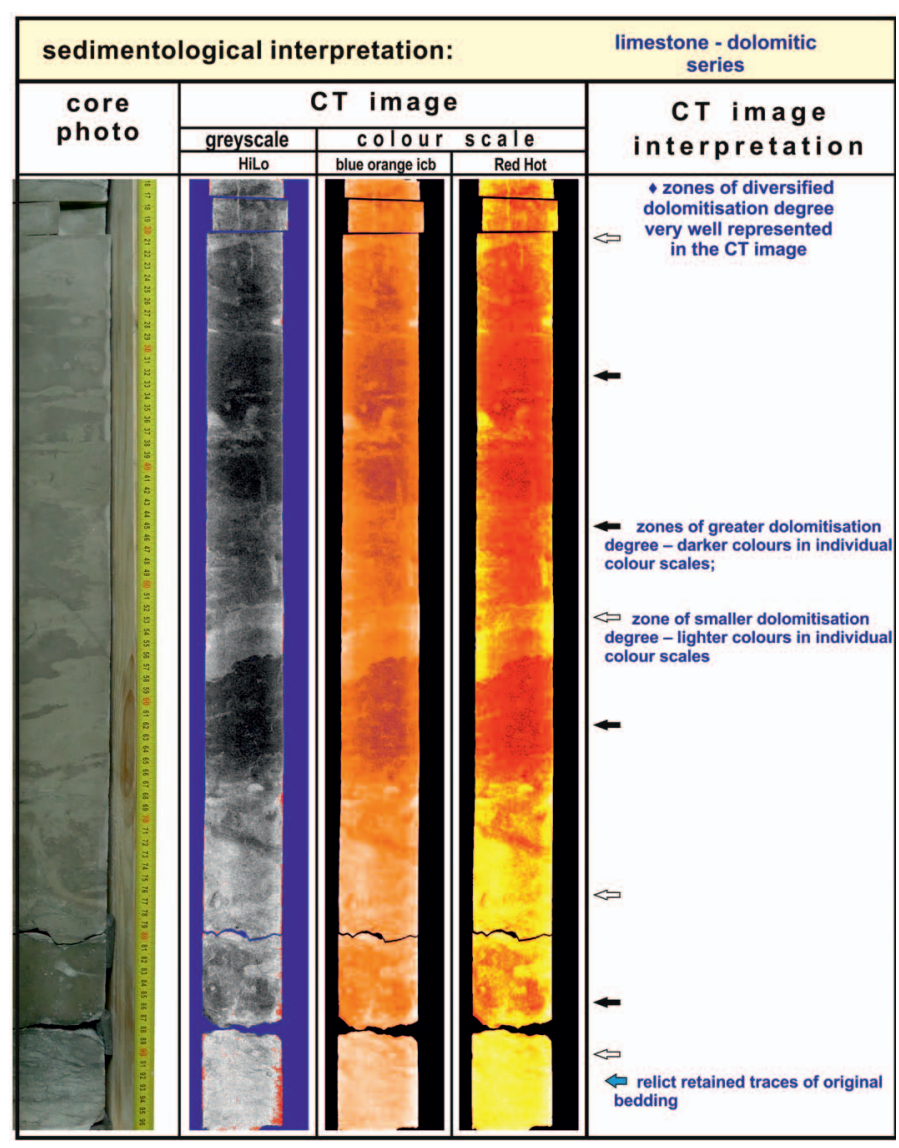

Fig. 3. CT image interpretation for a limestone-dolomitic series

\section{Porosity and cavernosity}

The term of porosity is usually understood as a rock property, manifesting itself by the existence of void spaces within its volume. Porosity is normally defined as a coefficient, as a ratio of total pores volume to the total volume of a rock sample. It can have original nature, related to the presence of void spaces between or inside individual rock components (e.g. growth-framework, interparticle, intraparticle porosity, etc.) or secondary nature, resulting from the influence of 
diagenetic processes or the activity of organisms (e.g. porosity originating from dissolution, dolomitization, boring organisms activity etc.).

The cavernous structure is most typical of dolomitic rocks and originates usually as a result of selective dissolution of individual rock components (e.g. bioclasts) or in places of the action of solutions resulting in dissolving some parties of carbonate rocks.

As detailed as possible characteristic of the pore space, as the basic element deciding about reservoir properties of carbonate rocks, is now very important, both in petroleum explorations and in geothermics. The method of X-ray computed microtomography (micro-CT) can be one of methods to study the pore space in rock samples, allowing to obtain a fully three-dimensional image of pores [48, incl. references]. This method is now frequently used to assess reservoir properties of carbonate rocks, including in particular to study the pores and fractures distribution, as well as to estimate both the porosity and the permeability ratios $[15,16,44,49]$. The processing of a $3 \mathrm{D}$ image enables to obtain various types of information related to the internal structure of the studied sample, such as the number and length of pores, their connections, directions, and structure [7, 48].

Among the analysed core samples the attention was drawn to a series of highly porous, and in places cavernous dolomites of the Upper Jurassic (Figures 4, 5). Porosity existing there to is mainly secondary nature, developed via selective dissolution of bioclasts, including in particular shells of gastropods existing in abundance in this interval, but also it is partly the effect of dolomitization processes. It is possible to presu-

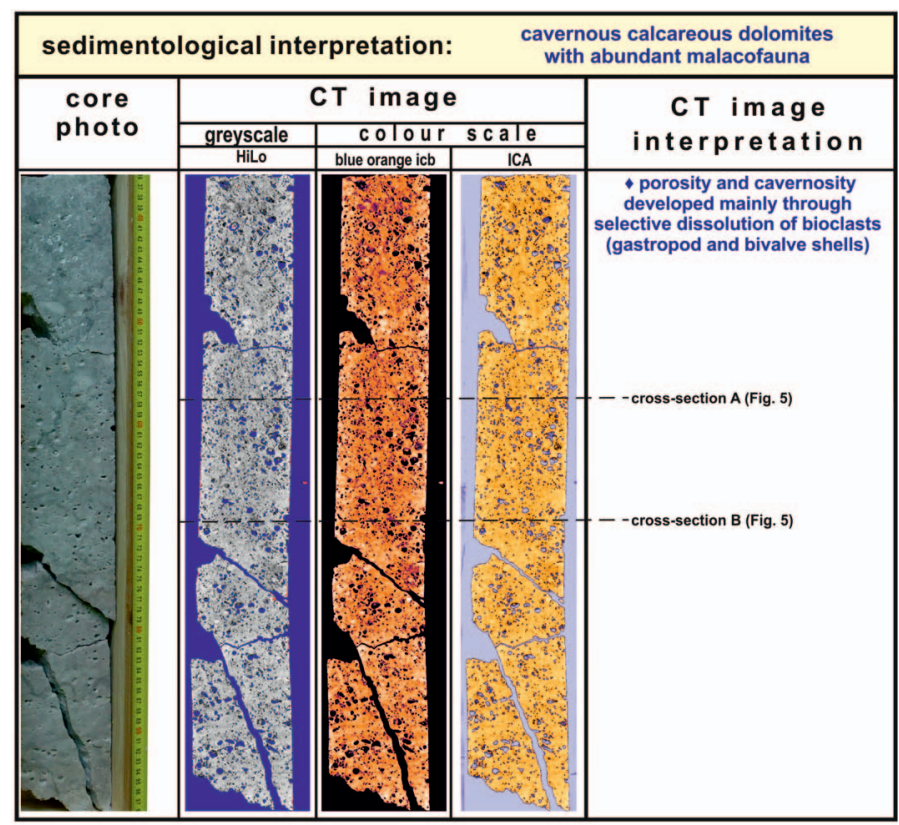

Fig. 4. CT image interpretation for a series of highly porous calcareous dolomites

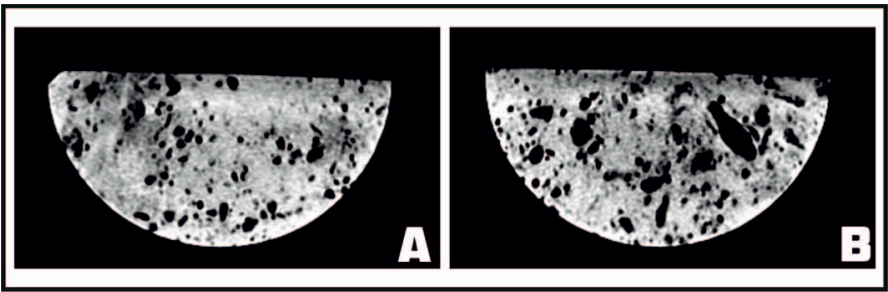

Fig. 5. Caverns created as a result of the dissolution of bioclasts in the CT image (A, B - various cross-sections, see Fig. 4)

me that originally the internal chambers of gastropods shells contained empty spaces, or were only partially filled with carbonate mud, which substantially increased due to proceeding dissolution and dolomitization processes.

Porosity, originated as a result of dolomitization processes, perfectly illustrated in a tomographic image, is presented based on a series of crystalline dolomites of the Upper Jurassic (Figure 6). The analysis of this image allows to conclude that the secondary porosity was developing mainly along lamination surfaces, because zones of clearly increased porosity are distributed mainly along those surfaces and have horizontal extent. An example of secondary porosity, developing

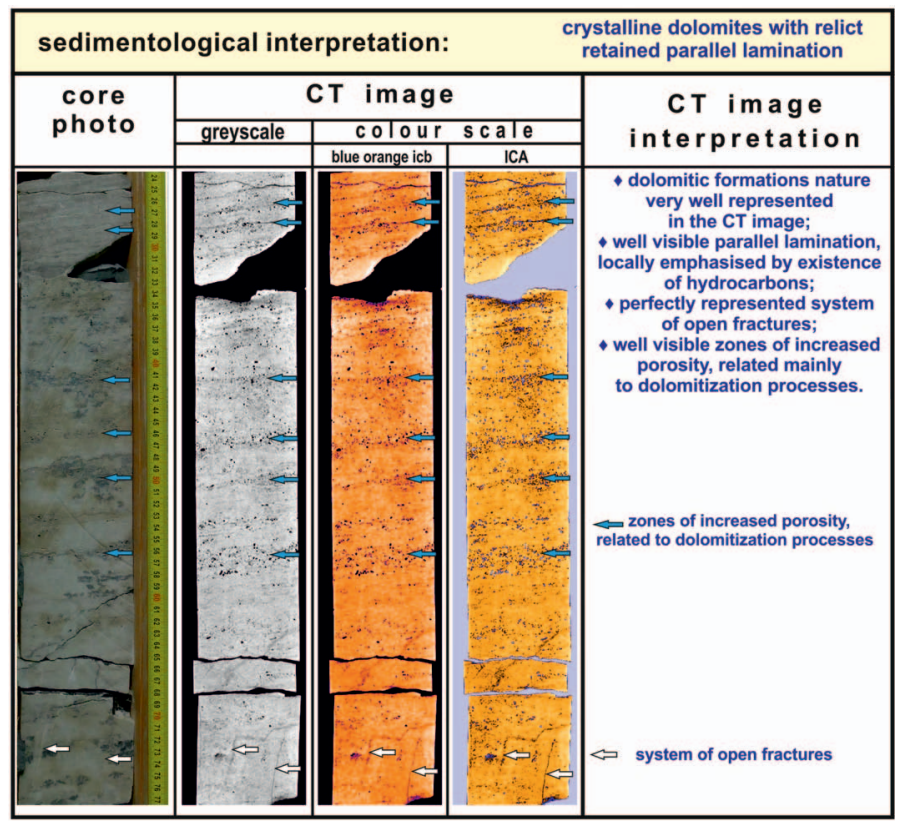

Fig. 6. CT image interpretation for a series of porous dolomites with relict retained parallel lamination
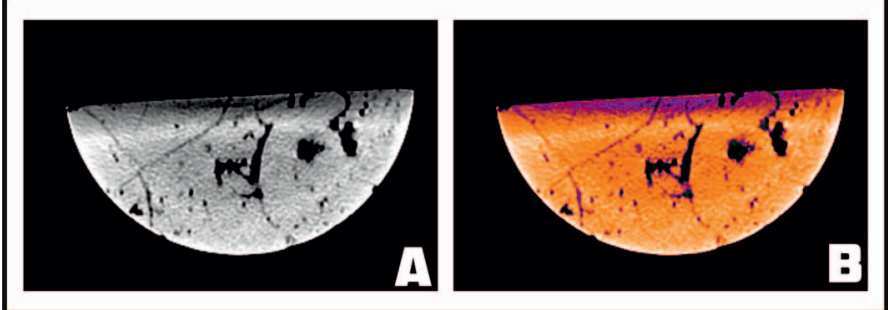

Fig. 7. An example of secondary porosity in dolomites, developed along fractures; A - using the greyscale, B - using the blue orange icb colour scale 
along fractures, is presented on a cross-section (Figure 7), in which it is clearly visible that zones of increased porosity are situated mainly along one of several existing fracture systems.

\section{Fractures and mineral fracture fills}

Fracturing is a very important feature of carbonate rocks, related to the existence within them, in natural conditions, of discontinuities (fractures) systems. The most generalised approach, taking into account the fractures genesis, distinguishes fractures of tectonic origin, diagenetic fractures, and thermal fractures. Currently there is a series of more detailed divisions of fractures, distinguished due to various criteria [vide e.g. $14,35]$. Fracturing is that important factor because basically almost all carbonate collectors are of a fracture or fracture-pore nature $[11,13,19,20,29]$. In addition, as a result of the solutions influence, utilising fracture systems existing in carbonate rocks, at the stage of epigenesis the development of dissolution and late cementation, and even metasomatic processes frequently takes place. Such processes occur under conditions of increased pressure, and frequently also at relatively high temperatures.

Carbonate rocks, originating from the uppermost part of the Upper Jurassic formation, presented in Figure 8, are an example of expanded fractures system (mostly open, and in places filled with calcite) existence. Hydrocarbons shows in the form of heavier petroleum fractions residues are present inside fractures. The described fractures system was very well represented in the tomographic image, based on which it is possible to assess the degree of filling with calcite cement.

\begin{tabular}{|c|c|c|c|}
\hline \multirow{3}{*}{$\begin{array}{c}\text { core } \\
\text { photo }\end{array}$} & & \multicolumn{2}{|c|}{ CT image } \\
\hline & & \multirow{2}{*}{$\begin{array}{r}\mathrm{col} O \mathrm{u} \\
\text { blue orange icb }\end{array}$} & \\
\hline & & & Red Hot \\
\hline & $\approx$ & & \\
\hline & $\stackrel{\mu}{\vec{\omega}}$ & & \\
\hline & 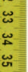 & & \\
\hline & $\underset{\Xi}{\Xi}$ & & \\
\hline & ๘ & & \\
\hline & & & \\
\hline
\end{tabular}

Fig. 8. Expanded fractures system (mostly open, and in places filled with calcite) in dolomitic limestones; arrows show hydrocarbon shows, visible on fracture surfaces, in the form of heavier petroleum fractions residues

Figure 9 presents a system of fractures, mostly filled with an clay-marly material, but also partly open or filled with calcite. Open and clay-marly filled fractures are visible very well in the tomographic image, while fractures filled with calcite are basically unrecognisable.

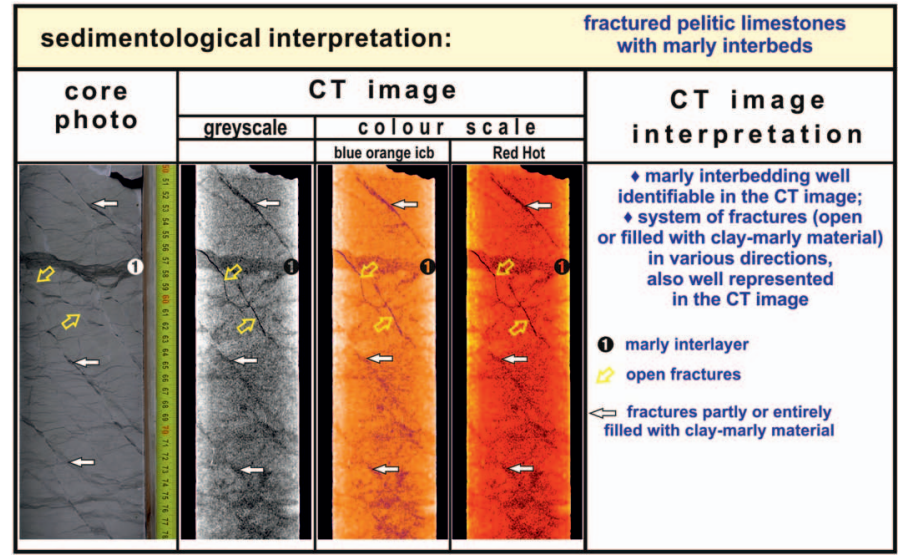

Fig. 9. CT image interpretation for pelitic limestones with an expanded system of fractures, partly open, and partly filled with a clay-marly material

The presented study comprised also the analysis of examples of anhydrite existence in carbonate formations. Anhydrite in carbonates is most often encountered in the form of cements, filling voids (e.g. fractures) existing within the rocks.

A complicated system of fractures, to a large extent filled with anhydrite cement, was found in Devonian dolomites (Figures 10,11). A complicated system of mineral veins and pocket-type concentrations of anhydrite was perfectly represented in the $\mathrm{CT}$ image, which is result of density differences between dolomite and anhydrite. In the described formation also smaller open fractures are very well visible, which locally create a dense network of branching fractures, perfectly visible in cross-sections perpendicular to the core axis (Figure 11).

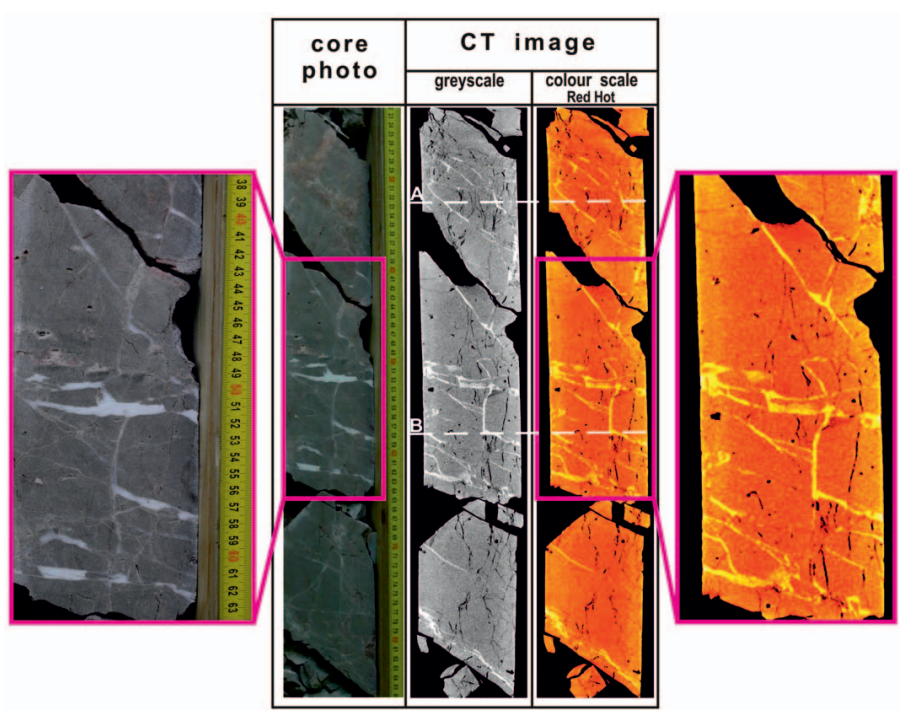

Fig. 10. CT images of dolomites with numerous veins and pocket-type concentrations of anhydrite (white or lightyellow on the CT image) and with open fractures (black on the CT image); A and B - location of cross-sections presented in Fig. 11 


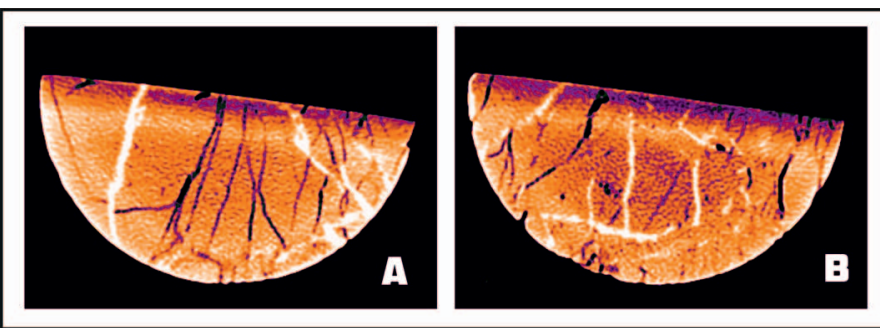

Fig. 11. Dolomites with anhydrite veins and with a network of open fractures (A, B - various cross-sections, see Fig. 10)

\section{Skeletal components of organisms}

$\underline{\text { Siliceous sponges }}$

Sponges are an important group of rock-forming organisms, widely encountered in carbonate formations from various stages and epochs. Their largest accumulations are related to the Upper Jurassic carbonate formations, where they constituted one of basic groups of organisms forming the skeletal mass of organic buildups [e.g. 1, 12, 21, 22, 28, 39].

A siliceous skeleton can be produced by sponges belonging to two different classes: Demospongiae and Hexactinella, where Hexactinella skeletons feature a higher silica content than skeletons of the majority of siliceous Demospongiae (except for lithistids) [40]. As fossils the siliceous sponges are preserved in a calcified form, as so-called 'mummies' $[17,23]$, originating from the decomposition of the soft tissue of sponge body, which is replaced with carbonate micrite [2]. Such micrite is referred to as 'container organomicrite' $[30,31]$. Siliceous spicules of sponges are most often entirely dissolved and replaced with calcite or dolomite. Quite numerous epifaunal organisms (such as bryozoans, corals, polychaetes, bivalves, numerous incrusting microorganisms) exist usually on the surface of sponge bodies $[1,38]$.

The scan quality of sponges structure in the $\mathrm{CT}$ image depends mainly on the history of diagenetic processes affected the studied sediments. In the limestones where sponge structures are well preserved and easily recognisable at the macroscopic description of drill cores (Figure 12), a uniform, nearly structureless scan is obtained in the CT image, within which it is not possible to distinguish any elements.

In other cases, in sediments that were macroscopically described as dolomitic-marly limestones with intraclasts and macrofauna, the sponge structures are also rather poorly recorded in the CT image, however they are noticeable in the form of darker patches with some details of internal structure, characteristic for sponges (Figure 13). Coral limestones exist in the same core interval have been very reliably reproduced in the tomographic image. The structure of individual corallites as well as details of skeletons are clearly visible (Figure 13). Mummified siliceous sponges were best represented in the $\mathrm{CT}$ image in biohermal sediments, which were subject to selective dolomitiza-

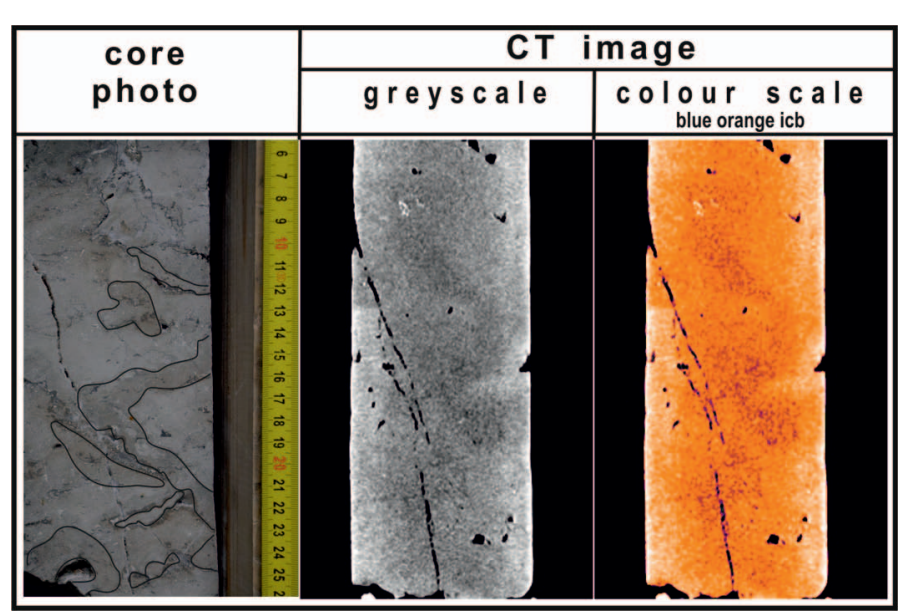

Fig. 12. Mummies of siliceous sponges (outlines on the core surface) practically entirely invisible in the CT image

tion (Figure 14). This effect is most likely related to the fact that sponge mummies are not subject to dolomitization, while the background sediments are subject to this process. This phenomenon was observed inter alia by Vierek [41] in Upper Jurassic limestones in the Cracow region, and also described in detail by Bodzioch [2] based on studies of Lower Muschelkalk carbonate deposits belonging to the Karchowice formation in the Opole region. In accordance to the Bodzioch's [2] interpretation, as a result of quick burying of a sponge body or of a large mass of soft tissues and of epidermis, a specific anoxic microenvironment forms in the deposit. First, as a result of soft tissues decomposition, pyrite is crystallised and then, with depleting amount of the soft tissue - micrite is precipitated.

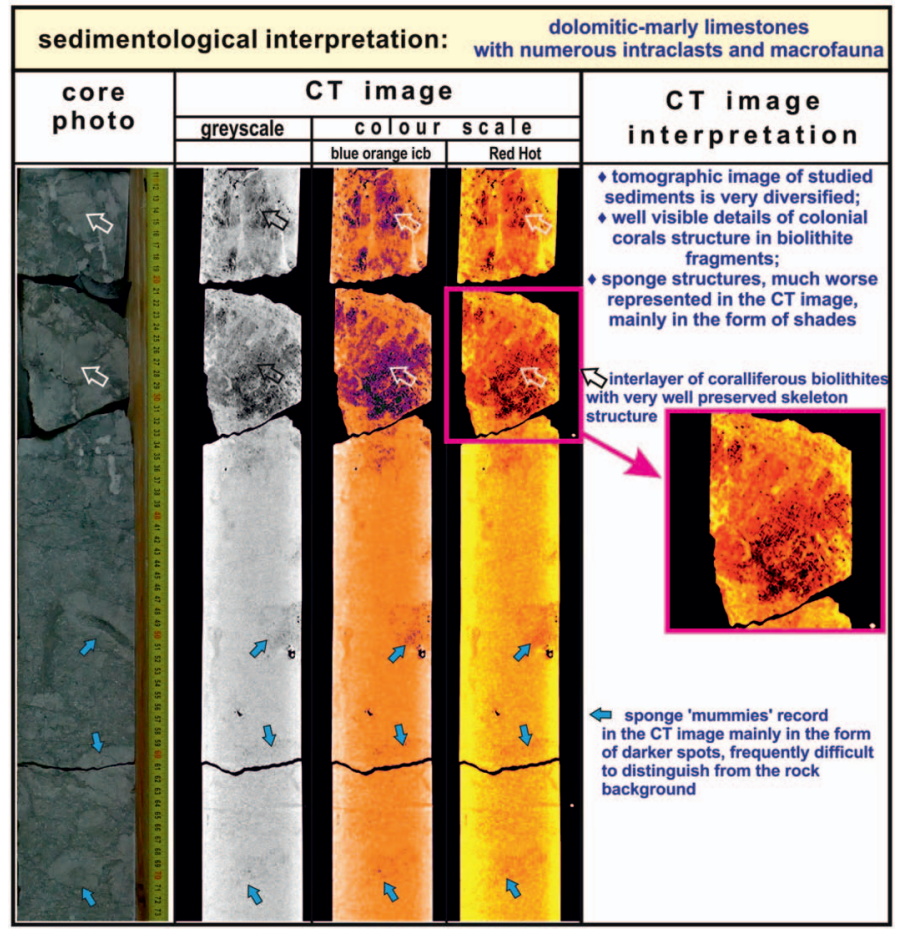

Fig. 13. CT image interpretation for a series of dolomitic-marly limestones with colonial corals and mummified siliceous sponges 


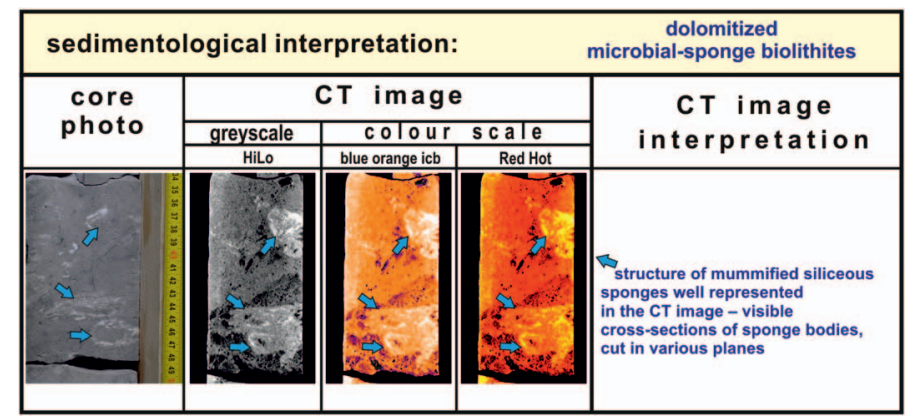

Fig. 14. CT image of mummified siliceous sponges in partly dolomitised spongy-microbial biolithites

\section{Colonial corals}

Corals constitute a group of marine organisms, diverse and widely encountered in carbonate deposits, of high rock-forming importance. Palaeozoic corals represent two most widespread groups: tabulate corals (Tabulata) and tetracorals (Rugo$s a$, which became extinct at the end of Permian [8-10]. Scleractinia corals belonging to hexacorals (Hexacorallia) were most widespread in Mesozoic [26, 32, 33]. Skeletal components of contemporary Scleractinia are built of aragonite [25], however Palaeozoic Rugosa corals had originally calcite skeletons [6, incl. references], and the first occurrence of aragonite skeleton in such forms is known only from the late Permian $[8,43]$. Aragonite skeletons were possessed certainly by the Triassic Scleractinia [36].

On the basis of carried out studies it is possible to state that the quality of corals skeletal structure representation in the CT image depends mostly on the preservation state of original carbonate formations structure, including in particular on the history of diagenetic processes. Good effects, in terms of structure representation, were obtained for hexacorals from the Scleractinia group, which featured a slightly bigger diameter of corallites, such as representatives of Montlivaltiidae family (Figures 13, 15, 16). Many details of skeleton structure, such as septa, size and general habit of corralites, are visible in the tomographic image of this group. The analysis of cross-sections perpendicular to the colony growth direction, provides further detailed information, in particular on individual corralites habit, as well as on the way of their arrangement and packing within the colony. This information can be very helpful at the preliminary identification of analysed specimens, especially in the cases, where such elements are invisible or poorly marked on the core surface.

In the case of more massive corals with integrated skeleton and at the same time very small, sometimes even macroscopically non-distinguishable corallites (such as Microsolenidae), it is possible to state that the obtained tomographic image is definitely more uniform, or even adopts a structureless nature (Figure 15). The difference in density between the coral li- mestones and the background sediment causes that the massive corals structure can be clearly identified in CT image. In such cases much better results are obtained based on the analysis of cross-sections perpendicular to the colony growth direction (Figure 17).

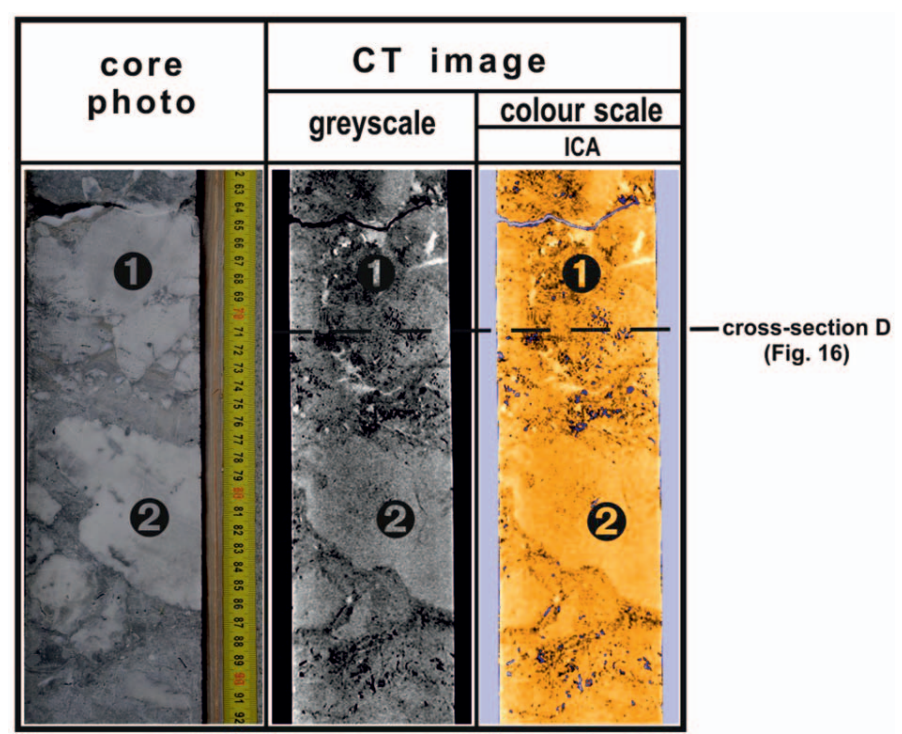

Fig. 15. Comparison of CT image for two groups of corals: 1 - corals from the Montlivaltiidae family, 2 - corals from the Microsolenidae family
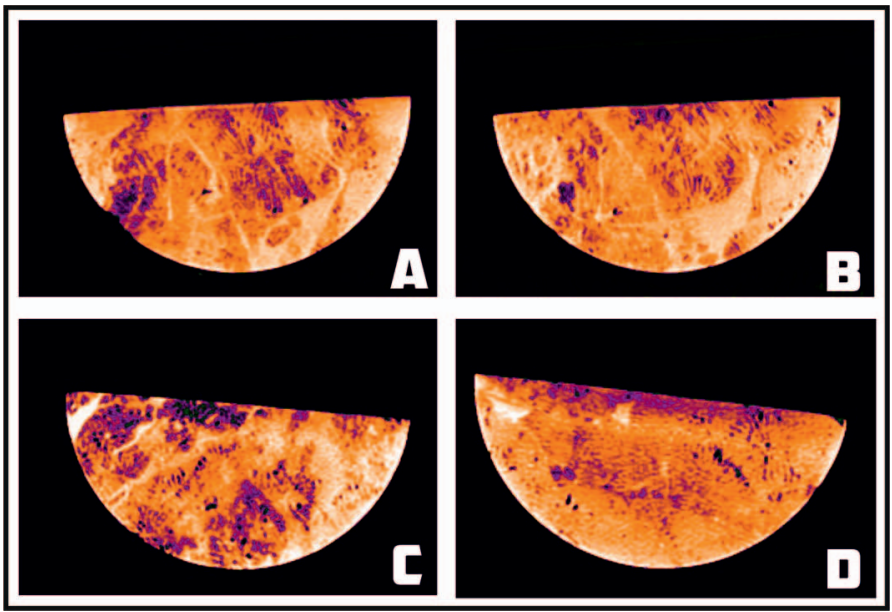

Fig. 16. CT image for colonial corals from the Montlivaltiidae family (A, B, C, D - various cross-sections)
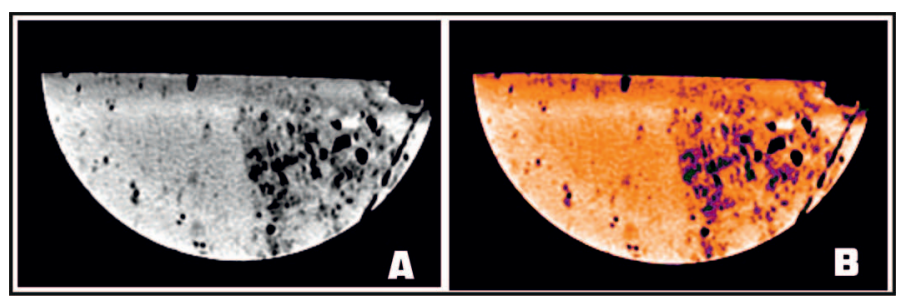

Fig. 17. CT image for a colony of corals; coral structure is locally affected by dissolution processes; A - using the greyscale, B - using the blue orange icb colour scale 


\section{Summary and conclusions}

The method of X-ray computed tomography (CT) can be very helpful at the analysis of various carbonate rocks features, such as structural and textural features, biogenic structures, porosity, as well as in reconstructing the spatial network of fracturing. This is a non-invasive method, providing a possibility to reflect the CT image in various directions, without the necessity of mechanical interference in the rock material, resulting in the core destruction.

Among the studied biogenic structures the best results were obtained for colonial corals. Mummified siliceous sponges were best represented in the CT image in sediments, which were subject to selective dolomitization, because sponge mummies do not get dolomitized, while the background sediments are subject to this process. Good results were obtained for hexacorals from the Scleractinia group with a slightly larger diameter of corallites (e.g. corals from the Montlivaltiidae family). Many details of the skeleton structure are visible in the CT image. Contrary to siliceous sponges the structure of corals is poorly visible in the case, when the studied formations have been subjected to diagenetic processes (including in particular dissolution, recrystallisation, and also dolomitization).

The analysis of various bioclasts, preserved in carbonate rocks, has shown a significant role both of the original mineral component building skeletal elements of organisms (depending on their systematic classifications as well as the age and environment of deposition) and of diagenetic processes history. The original mineral composition of skeletons of biological carbonate producers can vary depending on the sedimentation area. Generally aragonite and high-magnesium calcite are more typical for carbonate shelves, while low-magnesium calcite is more typical for the open sea $[24,34,46]$.
However, fossil carbonates are generally built of low-magnesium calcite due to the fact that aragonite and high-magnesium calcite are unstable.

Based on the analysed materials it was found that porosity and fracturing are among best represented features of carbonate rocks in the CT image. Open fractures as well as fractures filled with anhydrite or with clay-marly material are generally well reflected in the CT image. Fractures filled with calcite are variously recognisable, depending on the mineral composition of the rock background.

The realization of the X-ray computed tomography before the core halving and dividing into archive and so-called "working' parts can be very useful for the core documentation and archiving. The process of the core halving and taking material samples for laboratory studies brings about a possibility of losing certain important pieces of information. Which is especially important in the case of carbonate rocks. Carbonates can feature a very high variability (vertical and horizontal) even on a small core section (a few centimetres long). The tomographic examination, carried out in appropriate time, allows to preserve a complete image of the core, which later on can be used for various analyses, interpretations and reinterpretations (including geophysical logs and borehole imaging).

The application of the described method can be especially important for fractured carbonate formations. The drill core, taken from this kind of rocks, very often breaks down into small pieces. The description and interpretation of such core material could be very difficult. The realization of tomography at the stage prior to its halving, prevents the loss of important information and can contribute to much better learning of the structure and system of fractures.

Please cite as: Nafta-Gaz 2018, no. 3, pp. 183-192, DOI: 10.18668/NG.2018.03.01

Article contributed to the Editor 14.11.2017. Approved for publication 8.01.2018.

The article was written on the basis of the statutory study entitled: Cechy sedymentologiczne, biogeniczne i strukturalne skat weglanowych w odwzorowaniu tomografii komputerowej - INiG - PIB study commissioned by Ministry of Science and Higher Education; order number: 0025/SW/17, archival number: DK-4100-12/17.

\section{Literature}

[1] Bobrek L., Świetlik B., Urbaniec A.: Zespoły faunistyczne bioherm późnojurajskich środkowej części przedgórza polskich Karpat. XVII Konferencja Paleontologów „Historia basenów sedymentacyjnych a zapis paleontologiczny”, Kraków 2000. Materiały Konferencyjne, pp. 18-20.

[2] Bodzioch A.: Biogeochemiczna diageneza dolnego wapienia muszlowego Opolszczyzny. Wydawnictwo Naukowe Uniwersytetu im. A. Mickiewicza w Poznaniu, Seria Geologia 2005, no. 17, 130 p., ISBN 83-232-1572-3.

[3] Cebulski D., Urbaniec A., Kasprzyk K.: Obrazowanie wybranych własności utworów solnych za pomoca różnych me- tod badawczych. Nafta-Gaz 2017, no. 4, pp. 227-235, DOI: 10.18668/NG.2017.04.02.

[4] Chilingarian G.V., Mazzullo S.J., Rieke H.H. (eds): Developments in Petroleum Science 44, Carbonate reservoir characterization: a geologic-engineering analysis, part II. Elsevier 1996, pp. 135-142.

[5] Christe P., Turberg P., Labiouse V., Meuli R., Parriaux A.: An $X$-ray computed tomography-based index to characterize the quality of cataclastic carbonate rock samples. Engineering Geology 2011, vol. 117, issues 3-4, pp. 180-188, DOI: 10.1016/ j.enggeo.2010.10.016. 
[6] Cuif J.P.: The Rugosa-Scleractinia gap re-examined through microstructural and biochemical evidence: A tribute to H.C. Wang. Palaeoworld 2014, vol. 23, issue 1, pp. 1-14, DOI: 10.1016/j.palwor.2013.11.005.

[7] Dohnalik M., Zalewska J.: Pomiary porowatości skat metoda rentgenowskiej mikrotomografii komputerowej (Micro-CT). Geologia (Kwartalnik AGH) 2009, vol. 35, no. 2/1, pp. 617-624.

[8] Ezaki Y.: The Permian coral Numidiaphyllum: new insights into Anthozoan phylogeny and Triassic Scleractinian origins. Palaeontology 1997, vol. 40, no. 1, pp. 1-14.

[9] Fedorowski J.: Extinction of Rugosa and Tabulata near the Permian-Triassic boundary. Acta Palaeontologica Polonica 1989, vol. 34, issue 1, pp. 47-70.

[10] Fedorowski J.: Serpukhovian (Early Carboniferous) Rugosa (Anthozoa) from the Lublin Basin, eastern Poland. Annales Societatis Geologorum Poloniae 2015, vol. 85, no. 1, pp. 221-270.

[11] Garland J., Neilson J.E., Laubach S.E., Whidden K.J. (eds): Advances in carbonate exploration and reservoir analysis. Geological Society, London, Special Publications 2012, no. 370, pp. 1-15, DOI: 10.1144/SP370.15.

[12] Gliniak P., Gutowski J., Urbaniec A.: Budowle organiczne $w$ utworach górnej jury przedgórza Karpat - aktualny stan rozpoznania na podstawie interpretacji materiałów sejsmicznych $i$ wiertniczych $w$ kontekście poszukiwań złóż węglowodorów. Tomy Jurajskie 2005, vol. 3, pp. 29-43.

[13] Gliniak P., Laskowicz R., Urbaniec A., Such P., Leśniak G.: Skaty zbiornikowe w górnojurajskich utworach węlanowych w rejonie Zawada-Lękawica. Konferencja Naukowo-Techniczna „Ropa i gaz a skały węglanowe południowej Polski”, Czarna 16-18.04.2008, 12 p.

[14] Gudmundsson A.: Rock Fractures in Geological Processes. Cambridge University Press, Cambridge 2011, 578 p.

[15] Hicks P.J., Narayanan K., Deans H.A.: An experimental study of miscible displacement in heterogeneous carbonate cores using X-ray CT. SPE Formation Evaluation 1994, vol. 9, no. 1, pp. 55-60.

[16] Hidajat I., Mohanty K.K., Flaum M., Hirasaki G.: Study of vuggy carbonates using NMR and X-ray CT Scanning. SPE Reservoir Evaluation and Engineers, 88995 SPE Journal Paper 2004, vol. 7, no. 5, pp. 365-377.

[17] Hurcewicz H.: Typ Porifera. [W:] Malinowska L. (red.): Budowa geologiczna Polski, Atlas skamieniałości przewodnich i charakterystycznych, tom III, cz. 2b, Mezozoik, Jura. Wydawnictwa Geologiczne, Warszawa 1980, pp. 338-351.

[18] James N.P., Jones B.: Origin of carbonate sedimentary rocks. Wiley 2015, $446 \mathrm{p}$.

[19] Laskowicz R., Syrek-Moryc C., Urbaniec A.: Perspektywiczność utworów górnej jury przedgórza Karpat w świetle wyników prac poszukiwawczych w ostatnich latach. Konferencja Naukowo-Techniczna „Ropa i gaz a skały węglanowe południowej Polski”, Czarna 16-18.04.2008, 19 p.

[20] Laskowicz R., Syrek-Moryc C., Urbaniec A.: Rola stref dyslokacyjnych $w$ procesie ksztaltowania i napetniania pułapek złożowych w utworach górnej jury przedgórza Karpat w świetle najnowszych odkryć akumulacji węglowodorów. Prace Instytutu Nafty i Gazu 2008, no. 150, pp. 263-268.

[21] Leinfelder R.R., Krautter M., Nose M., Ramalho M.M., Werner W.: Siliceous sponge facies from the Upper Jurassic of Portugal. Neues Jahrbuch für Geologie und Paläontologie Abh. 1993, no. 189, pp. 199-254.

[22] Leinfelder R.R., Werner W., Nose M., Schmid D.U., Krautter M., Laternser R., Takacs M., Hartmann D.: Paleoecology, growth parameters and dynamics of coral, sponge and microbolite reefs from the Late Jurassic. [W:] Reitner J., Neuweiler F., Gunkel F. (red): Global and regional controls on biogenic sedimentation. I. Reef Evolution. Res. Reports. Göttinger Arb. Geol. Paläont. 1996, Sb. 2, pp. 227-248.

[23] Małecki J.: Gąbki krzemionkowe $i$ wapienne oksfordu z Zalasu pod Krakowem. Kwartalnik AGH, Geologia 2002, vol. 28, no. $1-3$, pp. $5-120$.

[24] Matyszkiewicz J.: Wybrane problemy diagenezy osadów węglanowych. Przegląd Geologiczny 1996, vol. 44, no. 6, pp. 596-603.

[25] Meibom A., Cuif J.P., Hillion F., Constantz B.R., JuilletLeclerc A., Dauphin Y., Watanabe T., Dunbar R.B.: Distribution of magnesium in coral skeleton. Geophysical Research Letters 2004, no. 31(L23306), pp. 1-4, DOI: 10.1029/2004GL021313.

[26] Morycowa E.: Corals from the Tithonian carbonate complex in the Dabrowa Tarnowska - Szczucin area (Polish Carpathian Foreland). Annales Societatis Geologorum Poloniae 2012, vol. 82, no. 1, pp. 1-38.

[27] Okabe H., Tsuchiya Y., Pentland C.H., Iglauer S., Blunt M.J.: Residual $\mathrm{CO}_{2}$ Saturation Distributions in Rock Samples Measured by X-ray CT. [W:] Alshibli K.A., Reed A.H. (eds.): Advances in Computed Tomography for Geomaterials: GeoX 2010. Wiley 2010, pp. 381-388, DOI: 10.1002/9781118557723.ch45.

[28] Pisera A.: What can we learn about siliceous sponges from palaeontology. Boll. Mus. Ist. Biol. Univ. Genova 2004, vol. 68, pp. 55-69.

[29] Reijers T.J.A.: Sedimentology and diagenesis as 'hydrocarbon exploration tools' in the Late Permian Zechstein-2 Carbonate Member (NE Netherlands). Geologos 2012, vol. 18, no. 3, pp. 163-195, DOI: 10.2478/v10118-012-0009-x.

[30] Reitner J.: Modern cryptic microbialite/metazoan facies from Lizard Islands (Great barrier Reef, Australia) formation and concepts. Facies 1993, vol. 29, pp. 2-40.

[31] Reitner J., Neuweiler F., Gautret P.: Modern and fossil automicrites: Implications for mud mound genesis. [W:] Reitner J., Neuweiler F. (coordination) Mud Mounds: A polygenic spectrum of fine-grained carbonate buildups. Facies 1995, vol. 32, pp. 4-17.

[32] Roniewicz E.: Jurajskie korale w Polsce. Tomy Jurajskie 2004, vol. 2, pp. 83-97.

[33] Roniewicz E.: Kimmeridgian-Valanginian reef corals from the Moesian Platform from Bulgaria. Annales Societatis Geologorum Poloniae 2008, vol. 78, no. 2, pp. 91-134.

[34] Sandberg P.A.: An oscillating trend in Phanerozoic non-skeletal carbonate mineralogy. Nature 1983, no. 305, pp. 19-22.

[35] Singhal B.B.S., Gupta R.P.: Applied Hydrogeology of Fractured Rocks (second edition). Wyd. Springer Dordrecht Heidelberg London New York 2010, 408 p., DOI: 10.1007/978-90-4818799-7.

[36] Stolarski J.: Three-dimensional micro- and nanostructural characteristics of the scleractinian coral skeleton: A biocalcification proxy. Acta Palaeontologica Polonica 2003, vol. 48, issue 4, pp. 497-530.

[37] Strzetelski W.: Rozwój procesów stylolityzacji i deformacji epigenetycznych $w$ aspekcie roponośności piaskowców kwarcytowych kambru środkowego w rejonie Żarnowca. Rocznik Polskiego Towarzystwa Geologicznego 1977, vol. 47, no. 4, pp. 559-584.

[38] Świerczewska-Gładysz E.: Gąbki z górnego turonu i dolnego koniaku niecki opolskiej - aktualny stan badań. [W:] Kędzierski M. i Kołodziej B. (red.), XXII Konferencja Naukowa Sekcji Paleontologicznej Polskiego Towarzystwa Geologicznego, „Aktualizm i antyaktualizm w paleontologii”, Tyniec 27-30.09.2013, Materiały Konferencyjne, pp. 61-62. 
[39] Trammer J.: Middle to Upper Oxfordian sponges of the Polish Jura. Acta Geologica Polonica 1989, vol. 39, no. 1-4, pp. 49-91.

[40] Uriz M.J.: Mineral skeletogenesis in sponges. Canadian Journal Zoology 2006, vol. 84, no. 2, pp. 322-356, DOI: 10.1139/z06-032.

[41] Vierek A.: Przejawy procesów metasomatycznych $w$ wapieniach górnej jury z okolic Krakowa. Przegląd Geologiczny 2003, vol. 51, no. 6, pp. 507-516.

[42] Watanabe Y., Lenoir N., Hall S.A., Otani J.: Strain field measurements in sand under triaxial compression using X-ray $C T$ data and digital image correlation. [W:] Alshibli K.A., Reed A.H. (eds.): Advances in Computed Tomography for Geomaterials: GeoX 2010. Wiley 2010, pp. 76-83. DOI: 10.1002/9781118557723.ch9.

[43] Wendt J.: The first aragonitic rugose coral. Journal of Paleontology 1990, vol. 64, no. 3, pp. 335-340.

[44] Withjack E.M., Devier C., Michael G.: The role of X-ray Computed Tomography in core analysis. 83467 SPE Journal Paper 2003, pp. 1-12.

[45] Yun T.S., Jeong Y.J., Kim K.Y., Min K.-B.: Evaluation of rock anisotropy using $3 D X$-ray computed tomography. Engineering Geology 2013, vol. 163, pp. 11-19, DOI: 10.1016/j.enggeo.2013.05.017.

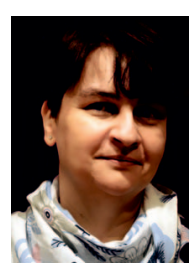

Katarzyna DRABIK M.Sc. Eng.

Senior engineering-technical specialist

in the Department of Well Logging

Oil and Gas Institute - National Research Institute

ul. Lubicz $25 \mathrm{~A}$

31-503 Kraków

E-mail:drabik@inig.pl
[46] Wilkinson B.H.: Biomineralization, paleoceanography and the evolution of calcareous marine organisms. Geology 1979, vol. 7, pp. 524-527.

[47] Wolański K., Zarudzki W., Kiersnowski H., Dohnalik M., Drabik K.: Wykorzystanie tomografii komputerowej w badaniu rdzeni skat. Nafta-Gaz 2016, no. 12, pp. 1035-1042, DOI: 10.18668/NG.2016.12.04.

[48] Zalewska J. (red.): Rentgenowska mikrotomografia komputerowa w badaniu skat węglanowych. Prace Naukowe Instytutu Nafty i Gazu 2010, no. 171, 263 p.

[49] Zalewska J., Kaczmarczyk J., Dohnalik M., Cebulski D., Poszytek A.: Analiza własności zbiornikowych skat węglanowych $z$ wykorzystaniem mikrotomografii rentgenowskiej. Nafta - Gaz 2010, no. 8, pp. 653-662.

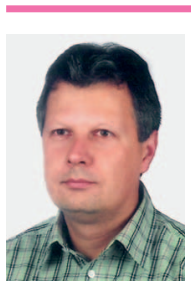

Andrzej URBANIEC M.Sc.

Chief engineering-technical specialist

in the Department of Seismics

Oil and Gas Institute - National Research Institute

ul. Lubicz 25 A

31-503 Kraków

E-mail: urbaniec@inig.pl

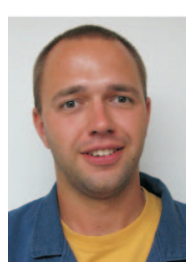

Marek DOHNALIK PhD Eng.

Assistant Professor

Head of the Department of Well Logging

Oil and Gas Institute - National Research Institute

ul. Lubicz 25 A

31-503 Kraków

E-mail:dohnalik@inig.pl

\section{OFERTA}

\section{ZAKŁAD SEJSMIKI}

Zakres działania:

- $\quad$ interpretacja strukturalna i litofacjalna zdjęć sejsmicznych 2D i 3D;

- $\quad$ przetwarzanie danych sejsmicznych 2D/3D Prestack i Postack

- $\quad$ migracja sejsmiczna MGF-K w wersji Prestack i Postack w domenie czasu i głębokości z uwzgleednieniem anizotropii ośrodka typu VTI, TTI, HTI;

- interpretacja strukturalna i litofacjalna pomiarów sejsmicznych Prestack i Postack 2D oraz 3D;

- $\quad$ przetwarzanie i interpretacja pionowych profilowań sejsmicznych PPS $1 C, 3 C$

- budowa modeli predkościowych na podstawie analiz danych sejsmicznych i geofizycznych w domenie czasu i głębokości - konwersja czas-głębokość, migracja glębokościowa;

- $\quad$ interpretacja danych sejsmicznych 3D-3C oraz pomiarów sejsmiki otworowej PPS-3C;

- $\quad$ konstrukcja map powierzchniowych - czasowych i głębokościowych;

- zwiększenie dokładności identyfikacji ośrodka geologicznego poprzez modyfikacje charakterystyki widmowej zarejestrowanych danych sejsmicznych

- poprawa rozdzielczości danych sejsmicznych Postack - dekompozycja spektralna

- wieloatrybutowa charakterystyka ośrodka geologicznego;

- $\quad$ analizy sejsmiczne AVO, AVAZ

- $\quad$ obliczanie inwersji symultanicznej oraz stochastycznej;

- wykonywanie modelowania sejsmicznego:

- identyfikacja anizotropii typu HTI w ośrodku geologicznym przy użyciu danych sejsmicznych i otworowych - określenie intensywnośc oraz azymutu anizotropii;

- $\quad$ obliczanie parametrów anizotropii typu VTI i HTI oraz określenie głównych kierunków szczelinowatości na podstawie wieloazymutalnego pomiaru PPS 3 C i sejsmiki powierzchniowej;

- $\quad$ wyznaczanie poziomów złożowych (bright, dim oraz sweet spot) na danych Prestack oraz Postack;

- zastosowanie metod geostatycznych do konstrukcji statycznych i dynamicznych modeli złóż węglowodorów;

- $\quad$ prognozowanie ciśnień porowych na podstawie danych sejsmicznych i geofizycznych. 